\title{
Maximum ST Segment Depression by ECG
} Finding

National Cancer Institute

\section{Source}

National Cancer Institute. Maximum ST Segment Depression by ECG Finding. NCI

Thesaurus. Code C62163.

An electrocardiographic finding of the maximum depression of the ST segment, obtained from a set of measurements of the depression of the ST segment. 